Хомчак Р. Б., канд. військ. наук

(0000-0002-8492-7510)

Міністерство оборони України, Київ

\title{
Розвиток термінологічного апарату обгрунтування внесків видів (родів) військ у потрібний рівень босздатності Збройних Сил України під час їх застосування (відбиття збройної агресії)
}

Резюме. У статті запропоновано основні показники, що характеризують внески видів (родів) військ у потрібний рівень боєздатності Збройних Сил (3С) України під час їх застосування (відбиття збройної агресії) зі встановленою величиною відверненого збитку, які може бути використано під час розроблення термінологічного апарату обгрунтування внесків видів (родів) військ у потрібний рівень боєздатності ЗС України під час їх застосування (відбиття збройної агресії).

Ключові слова: боєздатність військ; внески видів (родів) військ у боєздатність; визначення внесків видів (родів); склад угруповання військ.

Постановка проблеми. Боєздатність ЗС, як свідчать проведені дослідження останніх років, обумовлена низкою зовнішніх $\mathrm{i}$ внутрішніх факторів, вплив яких відбивається по-різному. Проте найбільш важливим із факторів, який здійснює найвагоміший вплив на їі рівень, слід вважати склад видів ЗС та родів військ (спеціальних військ).

Успіх виконання завдань, поставлених перед певним військовим формуванням (об'єднанням, з'єднанням, частиною тощо), його внесок обумовлюють досягнення кінцевої мети. Отже, 3 огляду на це, є вкрай важливим й актуальним вирішення завдання, яке полягає в обгрунтуванні внесків видів (родів) військ у потрібний рівень боєздатності ЗС України під час ïx застосування (відбиття збройної агресії).

Слід відмітити, що на сьогодні методичного апарату обгрунтування внесків видів (родів) військ у потрібний рівень боєздатності ЗС України під час їх застосування немає, тому існує вкрай гостра потреба в його розробленні. Одним 3 етапів розроблення такого методичного апарату $є$ визначення основних показників, що характеризують внески видів (родів) військ у потрібний рівень боєздатності ЗС України.

Аналіз останніх досліджень i публікацій. Проведений у рамках дослідження аналіз показав, що питанню визначення внесків видів (родів) військ у боєздатність створюваного угруповання (бойового порядку) військових формувань присвячено декілька наукових праць [1-8], серед яких, насамперед, слід назвати монографію [1]. Адже варто наголосити, що в даній роботі зазначене питання представлене лише фрагментарно - в основному з погляду розкриття загального фізичного змісту поняття та теорії відверненого збитку військ під час операції (бойових дій).
Метою статті $\epsilon$ висвітлення основних показників, що характеризують внески видів (родів) військ у потрібний рівень боєздатності ЗС України під час їх застосування (відбиття збройної агресії) зі встановленою величиною відверненого збитку, які надалі будуть використані під час розроблення методичного апарату визначення внесків видів (родів) військ у потрібний рівень боєздатності ЗС України під час їх застосування (відбиття збройної агресії) зі встановленою величиною відверненого збитку.

Викладення основного матеріалу. Проведений аналіз застосування військ у збройних конфліктах, а також аналіз наукових праць, присвячених будівництву збройних сил, дали змогу визначити основні показники, які характеризують внески видів (родів) військ у потрібний рівень боєздатності ЗС України під час ï застосування (відбиття збройної агресіï) зі встановленою величиною відверненого збитку

Ці показники надалі будуть використані як вихідні дані для визначення внесків видів (родів) військ у потрібний рівень боєздатності ЗС України під час їх застосування (відбиття збройної агресії) зі встановленою величиною відверненого збитку.

До таких показників належать:

початковий бойовий потенціал $\Pi_{0 n p}$ або відповідна йому ( ) початкова (вихідна, прогнозована) кількість $N_{0 n p}$ військових формувань типу з'єднань (частин, підрозділів) або бойових засобів (зразків озброєння) противника, 3 урахуванням кількості $N_{\text {0inp }}$ його засобів ураження $i$-го типу $(i=\overline{1, v})$ : $\Pi_{0 n p} \square N_{0 n p}=\sum_{i} N_{0 i n p} ;$

початковий бойовий потенціал або відповідна йому ( ) початкова (вихідна, штатна) 
кількість $N_{0}$ військових формувань типу з'єднань (частин, підрозділів) або бойових засобів (зразків озброєння) наших військ, з урахуванням початкової кількості $N_{0 j}$ бойових засобів $j$-го $(j=\overline{1, r})$ роду військ, основними 3 яких, наприклад, стосовно Сухопутних військ, $€$ танкові, механізовані, артилерійські, зенітні з'єднання (частини, підрозділи), структура та організація яких багато в чому визначаються кількістю їх ОВТ основних видів (груп, типів): $\Pi_{0} \square N_{0}=\sum_{j} N_{0 j} ;$

прогнозоване відповідним штабом вихідне (початкове) співвідношення бойових потенціалів сторін, які протистоять, за всіма основними військовими формуваннями або бойовими засобами, у тому числі можливої початкової кількості $N_{0 n p}=\sum_{i} N_{\text {0inp }}$ бойових засобів противника, а також кількості $N_{\text {0inp }}$ його засобів ураження $i$-го типу, з урахуванням того, що початкова кількість бойових засобів наших військ становить $N_{0}=\sum_{j} N_{0 j} . \quad$ (розрахунок $\alpha_{o}$ здійснюється у стратегічному, оперативному та тактичному масштабах відповідними штабами у всій смузі дій, а також на головному та іншому напрямках дій військ): $\alpha_{0}=\frac{\Pi_{0 n p}}{\Pi_{0}} \square \frac{N_{0 n p}}{N_{0}}=\frac{\sum_{i} N_{0 i n p}}{\sum_{j} N_{0 j n p}}$; $N_{O}^{B u M}$ - потрібна (з урахуванням втрат) кількість бойових засобів усіх типів наших військ у розрахункових одиницях бойового потенціалу до початку операції для забезпечення коефіцієнта боєздатності (відносної величини бойового

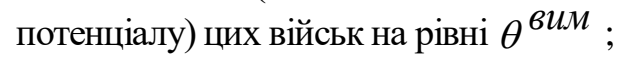

$$
\alpha=\frac{\Pi_{0 n p}}{\Pi_{0}^{\text {suм }}} \square \frac{N_{0 n p}}{N_{0}^{\text {su. }}} \leq \alpha_{0} \quad-\quad \text { досяжне }
$$

співвідношення бойових потенціалів сторін, які протистоять, до початку операції за усіма основними типами бойових засобів в умовах припустимих середньодобових за період $T$ бойових дій відносних втрат $\beta_{n}$ для забезпечення значення $\theta^{\text {вим }}$;

$$
P_{n p i}=\frac{\square N_{n p i}}{N_{\text {0inp }}}=\frac{\sum_{j} \square N_{n p j i}}{N_{\text {0inp }}}-\text { ймовірність }
$$

знищення силами та засобами всіх типів наших

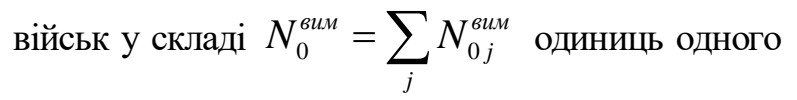

бойового засобу $i$-го типу противника 3 наявних $N_{\text {опр }}=\sum_{i} N_{\text {оinp }}$ одиниць;

$$
P_{j i}=\frac{\square N_{n p j i}}{N_{0 i n p}} P_{j i} \quad-\quad \text { ймовірність }
$$

знищення $j$-ми бойовими засобами наших військ хоча $б$ одного бойового засобу $i$-го типу противника;

поновлення (поповнення) військових формувань або бойових засобів сторін, які протистоять, замість втрачених (знищених) під час операції тривалістю $T$ діб не відбувається, але стосовно наших військ може бути враховано деякі заходи матеріально-технічного забезпечення (МТ3), пов'язані з відновленням з імовірністю $A$ пошкоджених бойових засобів під час бойових дій, через множник $\left[1-A\left(1-\beta_{\sigma_{6}}\right)\right], \quad 3$ урахуванням усередненої за всі роди наших військ прогнозованої середньодобової відносної величини безповоротних втрат $\beta_{\text {бв }}$ бойових засобів;

$$
\theta=\frac{N}{N_{0}}-\text { поточне значення коефіцієнта }
$$

(рівня) боєздатності (відносної величини бойового потенціалу) усіх військ в умовах середньодобових відносних втрат $\beta_{o}^{\prime}$ цих військ, тобто без урахування відверненого збитку;

$$
\theta_{j}=\frac{N_{j}}{N_{0 j}}=1-\beta_{0 j}^{\prime} \cdot T \quad-\quad \text { поточне }
$$

значення коефіцієнта (рівня) боєздатності (відносної величини бойового потенціалу) $j$-го виду ЗС або роду військ в умовах середньодобових відносних втрат $\beta_{0 j}^{\prime}$ цих військ, тобто без урахування відверненого збитку;

$$
\beta_{0 j}^{\prime}=\frac{\square N_{0 j}}{T \cdot N_{0 j}}=\frac{1-\theta_{j}}{T}-\text { нормативні }
$$

(прогнозовані) середньодобові за період $T$ відносні втрати, які визначаються для кожного $j$-го виду ЗС або роду військ;

$$
\beta_{0}^{\prime}=\frac{\square N_{0}}{T \cdot N_{0}} \text { - нормативні (прогнозовані) }
$$

середньодобові за період $T$ відносні втрати всіх військ, усереднені по $j$-х видах $3 \mathrm{C}$ або родах військ $(j=\overline{1, r})$;

$$
\beta_{n}=\frac{\square N_{n}^{\delta}}{T \cdot N_{0}^{\text {вим }}}=\frac{1-\theta^{\text {вuи }}}{T}-\text { припустимі }
$$

середньодобові за період $T$ відносні втрати бойових засобів усіх наших військ для забезпечення рівня боєздатності $\theta \geq \theta^{\text {вим }} \beta_{n}$ 
військ під час бойових дій;

$$
\beta_{n p i}=\frac{\square N_{n p i}}{T \cdot N_{0 i n p}} \text { середньодобові за період }
$$

$T$ відносні втрати бойових засобів $i$-го типу противника;

$$
\varphi_{j}^{(1)}-\text { величина внеску тільки } j \text {-го роду }
$$

наших військ у складі $N_{0}^{\text {вим }}$ од. у знищення бойових засобів усіх типів противника у складі $N_{\text {оnp }}=\sum_{i} N_{\text {0inp }}$ од.;

$\varphi_{i}$ - величина внеску всіх $j$-х родів наших військ у складі $N_{0}^{\text {вим }}=\sum_{j} N_{0 j}^{\text {вuм }}$ од. $(j=\overline{1, r})$ у знищення бойових засобів $i$-го типу противника зі складу $N_{0 n p}=\sum_{i} N_{0 i n p}$ од.;

$\varphi^{\text {вим }}$ - потрібна величина внеску всіх родів наших військ у знищення бойових засобів усіх типів противника у складі $N_{0 n p}=\sum_{i} N_{0 i n p}$ од. для забезпечення заданого рівня боєздатності $\theta^{\text {вим }}$ та необхідної для цього абсолютної величини відверненого збитку під час бойових дій;

$$
\varphi_{j c}^{(1)}-\text { внесок (“вартісний” внесок) окремо }
$$

діючого $j$-го роду наших військ, пов'язаний теж зі знищенням бойових засобів противника всіх типів, але 3 урахуванням затрат на створення цього роду військ;

$$
\varphi_{j c_{j}, c_{i n p}}^{(1)}-\text { величина внеску окремо діючого, }
$$

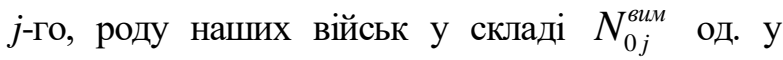
знищення бойових засобів усіх $i$-х типів противника у складі $N_{0 n p}=\sum_{i} N_{0 i n p} \quad$ од., 3 урахуванням співвідношення між вартостями $c_{j}, c_{i n p}$ бойових засобів сторін, які протистоять.

Висновки. У статті висвітлено показники, які характеризують внески видів (родів) військ у потрібний рівень боєздатності ЗС України під час їх застосування (відбиття збройної агресіі) зі встановленою величиною відверненого збитку.

Перспектива подальших досліджень полягає в розробленні 3 використанням запропонованих показників методичного апарату визначення внесків видів (родів) військ у потрібний рівень боєздатності 3С України під час їх застосування (відбиття збройної агресії) зі встановленою величиною відверненого збитку.

\section{ПЕРЕЛІК ВИКОРИСТАНОЇ ЛІТЕРАТУРИ}

1. Романченко I. C., Шуєнкін В. О., Можаровський В. М. Теорія відверненого збитку : монографія. Львів : НАСВ ЗС України, 2017. 244 с.

2. Хомчак Р. Б. Концептуальні складові обгрунтування та визначення внесків видів (родів) військ у потрібний рівень боєздатності Збройних Сил України під час їх застосування (відбиття збройної агресії). Збірник наукових пращь Центрального науководослідного інституту Збройних Сил України. Київ, 2019. № 5 (91). C. $25-31$.

3. Загорка О. М., Можаровський В. М., Фролов В. С., Загорка I. О. Методичний підхід до визначення бойового складу збройних сил воєнного та мирного часу. Збірник наукових прачь Центру воєнностратегічних досліджень Наиіонального університету оборони України імені Івана Черняховського. Київ, 2019. № 1 (65). С. 6-11. DOI: https://doi.org/10.33099/2304-2745/2019-1-65/6-11 (дата звернення: 19.08.2020).

4. Попко С. М., Муженко Д. П. Перспективи розвитку спроможностей Сухопутних військ Збройних Сил України. Наука і оборона. 2019. № 1. С. 3-8. DOI: https://doi.org/10.33099/2618-1614-2019-6-1-03-08 (дата звернення: 18.08.2020).

5. Дмитриев Е. В. Методика оценки боеспособности войск стратегического объединения. Научный сборник академии ГШ ВС СССР. Москва, 1988. № 28 (136). C. 134-143.

6. Голованов А. В., Скородід С. П. Обгрунтування показника оцінювання варіантів розподілу сил $\mathrm{i}$ засобів за напрямками у смузі оборони. Збірник наукових прачь Харківського начіонального університету Повітряних Сил. Харків, 2019. № 2 (60). C. 16-21. DOI: https://doi.org/10.30748/ zhups.2019.60.02 (дата звернення: 21.08.2020).

7. Дроль О. Ю., $\quad$ Гузченко С. В., $\quad$ Телюков С.М. Методика визначення оптимальної кількості та виду озброєння мобільних груп для забезпечення дій по стримуванню противника. Збірник наукових пращь Харківського наміонального університету Повітряних Сил. Харків, 2019. № 2 (64). С. 26-32. DOI: https://doi.org/10.30748/zhups.2020.64.04 (дата звернення: 21.08.2020).

8. Лобанов А. А., Мозговий В. А. До оцінювання ефективності управління військами. Наука і оборона. 2019. № 3. C. 3-9. DOI: https://doi.org/10.33099/ 26181614-2019-8-3-10-17 (дата звернення: 18.08.2020). 


\title{
Development of terminological apparatus of determining the contributions of services (branches) of troops in the required level of capacity of the armed forces of Ukraine during their application (counter of the armed aggression)
}

\begin{abstract}
Annotation
The combat effectiveness of the armed forces, according to recent studies, is due to a number of external and internal factors, the impact of which is reflected in different ways. However, the most important of the factors that have the most significant impact on its level should be considered the composition of the Armed Forces and the types of troops (special forces).

The analysis carried out within the framework of the research showed that several scientific works are devoted to the issue of determining the contributions of services (branches) of troops to the combat capability of the created group (battle array) of military formations. It should be noted that today there is no methodological apparatus for substantiating the contributions of services (branches) of troops to the required level of combat capability of the Armed Forces of Ukraine during their application, so there is an extremely urgent need for its development. One of the stages in the development of such a methodological apparatus is to determine the main indicators that characterize the contributions of types (branches) of troops to the required level of combat capability of the Armed Forces of Ukraine.

The article proposes the main indicators that characterize the contributions of services (branches) of troops to the required level of combat capability of the Armed Forces (AF) of Ukraine during their application (repulse of armed aggression) with a set amount of deterrence, which can be used during the development of terminological apparatus services (branches) of troops in the required level of combat capability of the Armed Forces of Ukraine during their use (repulse of armed aggression).

The prospect of further research is to develop using the proposed indicators of the methodological apparatus for determining the contributions of services (branches) of troops to the required level of combat capability of the Armed Forces of Ukraine during their application (repulse of armed aggression) with the established amount of deterrence.

Keywords: capacity of troops, contributions of services (branches) of troops in capacity; determining contributions of services (branches); composition of a group of troops.
\end{abstract}

